\title{
DOE/RW- -98005821
}

\author{
GEOLOGIC DISPOSAL OF HEU ALUMINUM-BASED DOE FUELS
}

J. Wesley Davis, Framatome Cogema Fuels and Peter Gottlieb, TRW

Civilian Radioactive Waste Management System, Management and Operating Contractor 1180 Town Center Drive

Las Vegas, NV 89134

(702)295-4557 / (702)295-4381

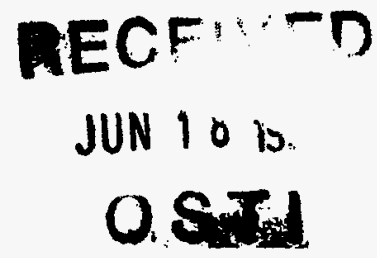

\section{INTRODUCTION}

This paper describes the disposal criticality analysis for canisters containing highly enriched uranium (HEU) in the form of aluminum-based Department of Energy spent nuclear fuel (DOE-SNF). The analysis is based on Massachusetts Institute of Technology (MIT) U-Al fuel with $93.5 \%$ enriched uranium which has a relatively heavy linear uranium loading. A canister design with 64 MIT assemblies (16/layer, 4 layers) totaling $35.2 \mathrm{~kg}$ of uranium was developed for this fuel type. A radial cross-sectional view of the MIT SNF canister is shown in Figure 1. Gadolinium phosphate $\left(\mathrm{GdPO}_{4}\right)$ distributed on, or in, carbon steel plates was incorporated into a carbon steel internal basket structure within a $439 \mathrm{~mm}$ OD, $15 \mathrm{~mm}$ thick XM-19 canister shell ${ }^{1}$. The DOE-SNF canister is placed in a Codisposal waste package (CWP) centered in a pentagonal array of five HLW canisters ${ }^{2}$ as shown in Figure 2. Figure 3 shows a radial cross-sectional view of the CWP configuration after emplacement in the repository. This analysis is limited to configurations inside the CWP.

\section{APPROACH}

The disposal criticality analysis methodology was applied to develop the following scenarios unique to the CWP in general, and the Al-based fuel in particular': 1) aqueous corrosion of stainless steel HLW and fuel containers; 2) degradation of HLW glass to clay; 3 ) degradation of Al-based fuel concurrent with or after the HLW glass; and 4) degradation of fuel canister basket materials including criticality control material, coupled with flushing soluble compounds from the CWP.

The EQ3/6 program ${ }^{3}$ was used to analyze the chemistry/geochemistry of the system. Parametric analyses were run on a range of possible distributions of fuel within the CWP using $\mathrm{MCNP}^{4}$ to identify the most reactive configurations and determine the minimum amount of neutron absorber required to be distributed with the fuel in its degraded configuration ${ }^{1}$.

\section{RESULTS}

The aluminum clad/aluminum matrix fuel could degrade through oxidation within a few decades after breach of the fuel canister. If the fuel canister were penetrated while the HLW glass was degrading, the chemistry (primarily $\mathrm{pH}>10.0$ ) would allow most of the uranium to dissolve given a sufficient volume of water flowing through the CWP. However, this scenario is not a criticality concern inside the CWP for two reasons: the low uranium concentration in solution and the presence of the large boron inventory within the HLW glass ${ }^{1}$.

Should the fuel canister be penetrated after the HLW glass were degraded, then the $\mathrm{pH}$ would be near neutral. The uranium would no longer be soluble and would remain in the canister or CWP. Three degraded configurations could result based on level of degradation and the location of the canister within the CWP: 1) degraded fuel material within the DOE-SNF canister as represented in Figure 4; 2) layers of hydrated aluminum, uranium, and iron oxides from the degraded DOE-SNF canister above the degraded HLW glass as represented in Figure 5; and 3) degraded products from the fuel mixed with various fractions of the degraded HLW glass as represented in Figure 6. The volume fraction of water in the degraded HLW and fuel, as well as the mass of iron oxide from the degraded canisters and basket, were varied in parametric criticality calculations. The bounding analysis of separation mechanisms indicates that no more than $14 \%$ of the iron and $\mathrm{GdPO}_{4}$ could be separated from the fuel as long as the basket and absorber plates degrade before the canister significantly corrodes away ${ }^{1}$. Based on theoretical analysis and review of literature on natural deposits, the small difference in density between the uranium bearing minerals, iron oxide, and the gadolinium-containing particulates in the degraded CWP will not result in significant stratification. 


\section{DISCLAIMER}

This report was prepared as an account of work sponsored by an agency of the United States Government. Neither the United States Government nor any agency thereof, nor any of their employees, makes any warranty, express or implied, or assumes any legal liability or responsibility for the accuracy, completeness, or usefulness of any information, apparatus, product, or process disclosed, or represents that its use would not infringe privately owned rights. Reference herein to any specific commercial product, process, or service by trade name, trademark, manufacturer, or otherwise does not necessarily constitute or imply its endorsement, recommendation, or favoring by the United States Government or any agency thereof. The views and opinions of authors expressed herein do not necessarily state or reflect those of the United States Government or any agency thereof. 
Analysis of the most reactive degraded fuel mixture in configuration 1 indicates that approximately $1.25 \mathrm{~kg}$ of Gd must be distributed in carbon steel plates in the intact canister basket ${ }^{1}$. After the carbon steel basket degrades resulting in a configuration like that shown in Figure 4, at least $1.1 \mathrm{~kg}$ of Gd would remain mixed with the fuel, while MCNP calculations indicate that less than $0.11 \mathrm{~kg}$ of $\mathrm{Gd}$ would be required ${ }^{1}$.

Analysis of configurations 2 and 3 (Figures 5 and 6), which occur after the DOE-SNF canister is severely degraded, indicate less than $0.01 \mathrm{~kg}$ Gd is required if credit is taken for the iron oxide produced from the degradation of the carbon steel basket structure and DOE-SNF canister shell ${ }^{1}$.

\section{CONCLUSIONS}

Without the presence of a fairly insoluble neutron absorber such as $\mathrm{GdPO}_{4}$, the long-term action of infiltrating water can lead to a small, but significant, probability of criticality for the HEU AI-based DOE-SNF ${ }^{1}$. More soluble absorbers such as boron were investigated but were found to be inadequate ${ }^{1}$. As an example, the MIT fuel (HEU) canister design was analyzed utilizing boron in stainless steel plates instead of $\mathrm{GdPO}_{4}$, resulting in a conservatively estimated probability of criticality of $7 \times 10^{-3}$ per canister. On the other hand, utilizing $1.25 \mathrm{~kg}$ of $\mathrm{Gd}\left(\mathrm{as} \mathrm{GdPO}_{4}\right.$ ) distributed in or on carbon steel absorber plates throughout the carbon steel basket will reduce the probability of criticality, during the first several hundred thousand years following emplacement, to virtually zero.

\section{ACKNOWLEDGEMENT}

This work was supported through the Westinghouse Savannah River Company, Savannah River Site (Contract Number DEAC01-91RW00134), by the DOE.

\section{REFERENCES}

1. Disposal Criticality Analysis for Aluminum-Based Fuel in a Codisposal Waste Package - ORR and MIT SNF Phase II, DI Number: BBA000000-01717-0200-00060 REV 00, CRWMS M\&O, December 1997.

2. Characteristics of Potential Repository Wastes, DOE/RW-0184-R1; Volume 1, U.S. DOE OCRWM, July 1992.

3. Wolery, Thomas J., EQ3/6, A Software Package for Geochemical Modeling of Aqueous Systems: Package Overview and Installation Guide (Version 7.0), UCRL-MA-110662 PT I, LLNL, 1992.

4. Briesmeister, Judith F., Editor, MCNP - A General Monte Carlo N-Particle Transport Code, Version 4A, LA-12625M, LANL, November 1993. 


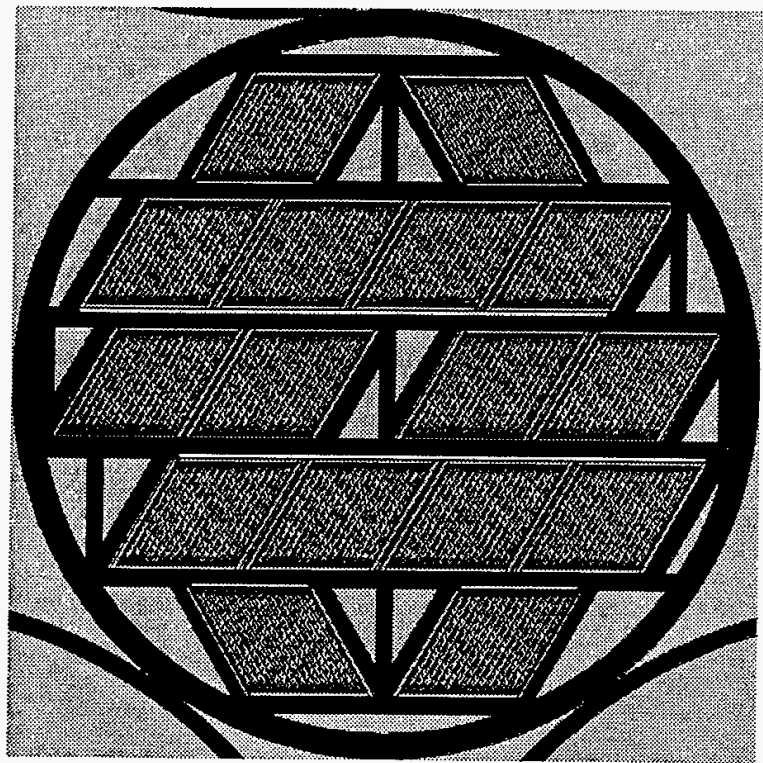

Figure 1. DOE-SNF Codisposal Canister for MIT SNF

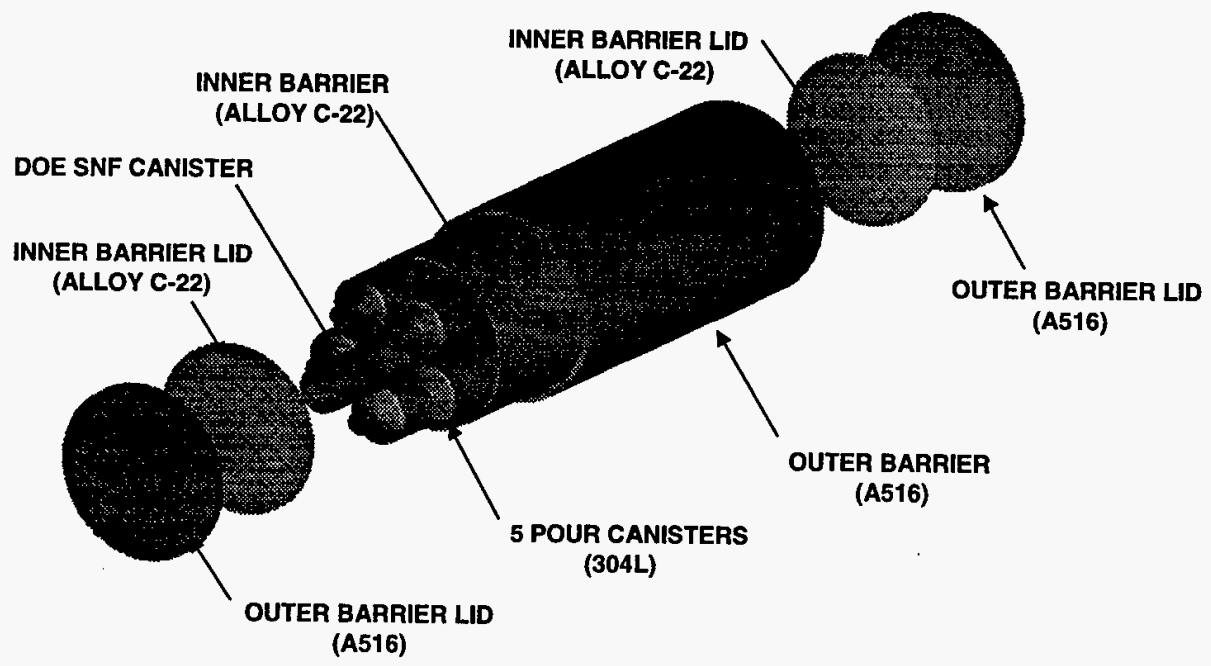

LENGTH $=3790 \mathrm{~mm}$ DIAMETER $=1970 \mathrm{~mm}$ TARE WEIGHT $=24,782 \mathrm{~kg}$ LOADED WEIGHT $=35,692 \mathrm{~kg}$

Figure 2. Codisposal Waste Package Assembly 


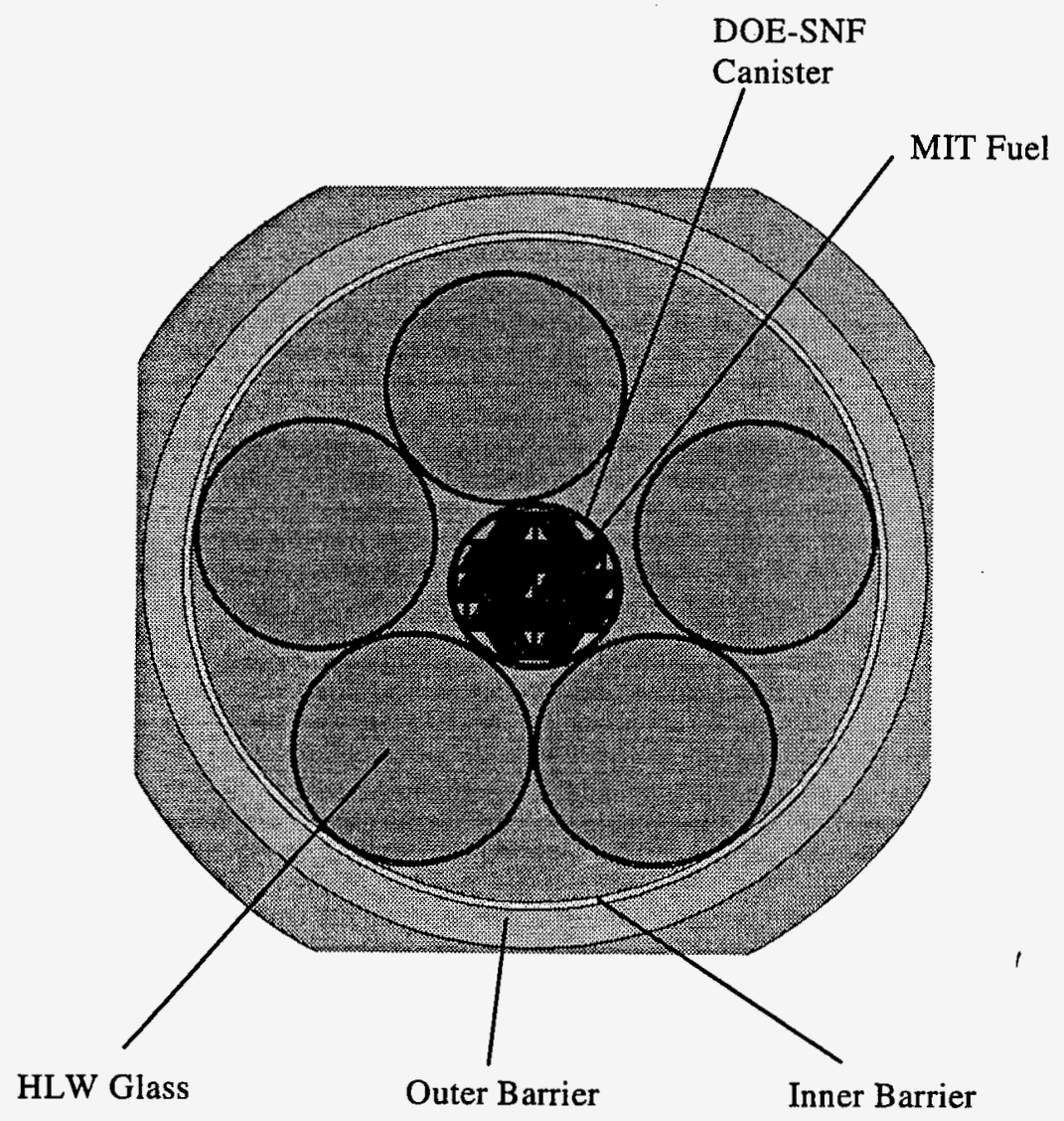

Figure 3. Codisposal Waste Package with an MIT SNF Canister

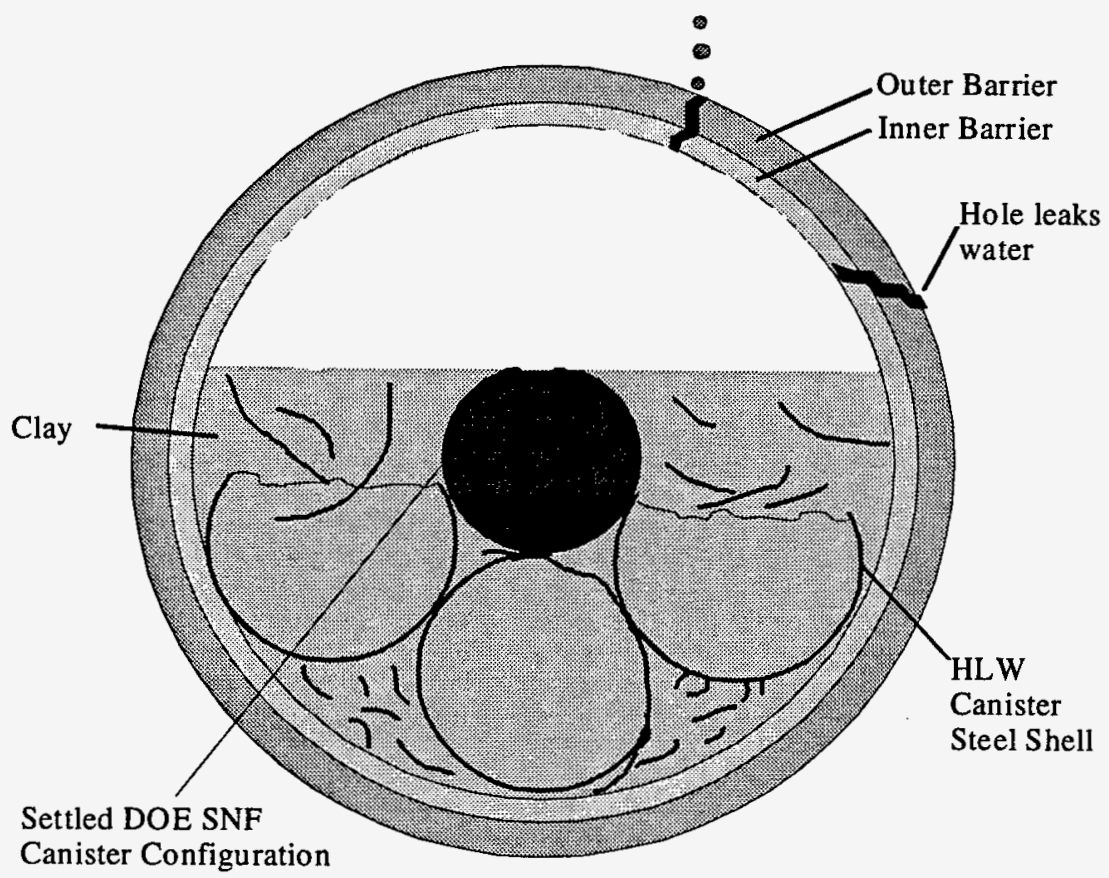

Figure 4. Degraded DOE-SNF and HLW Canisters 


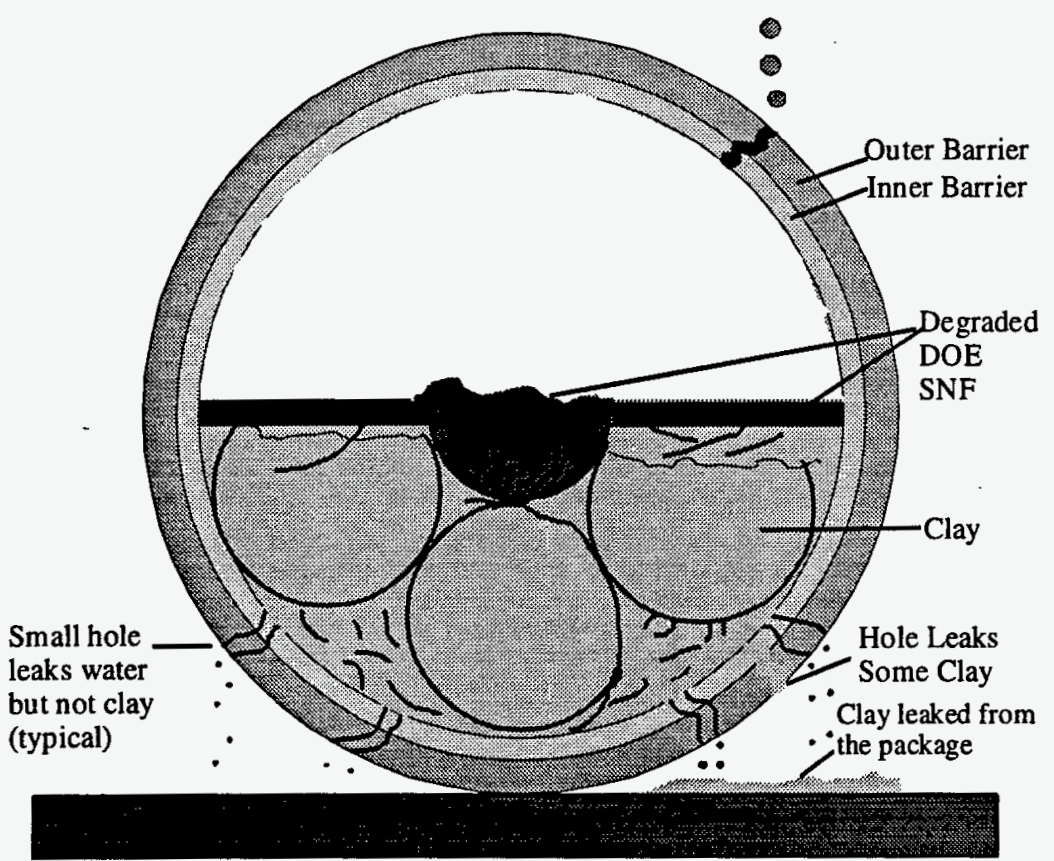

Figure 5. Degraded DOE SNF on Top of Degraded HLW

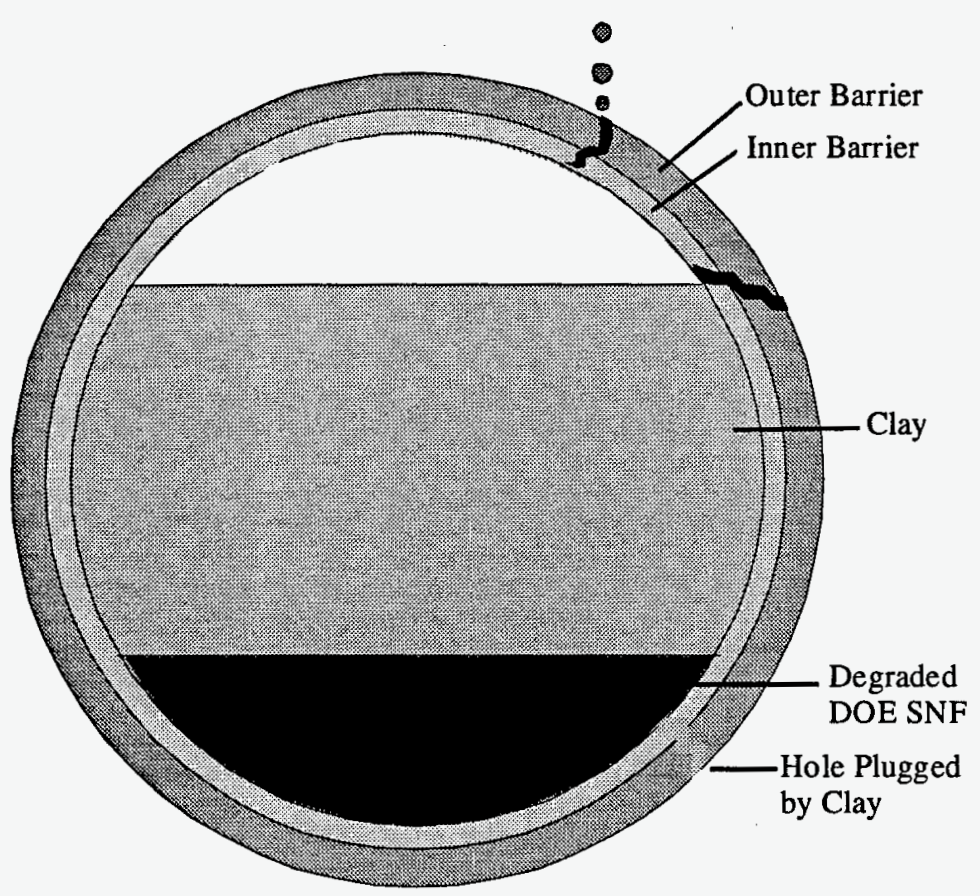

Figure 6. Degraded Codisposal Canister and Contents Mixed With Degraded HLW 


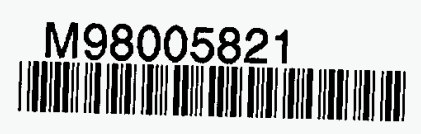

Report Number (14) DOE/RW--98005821

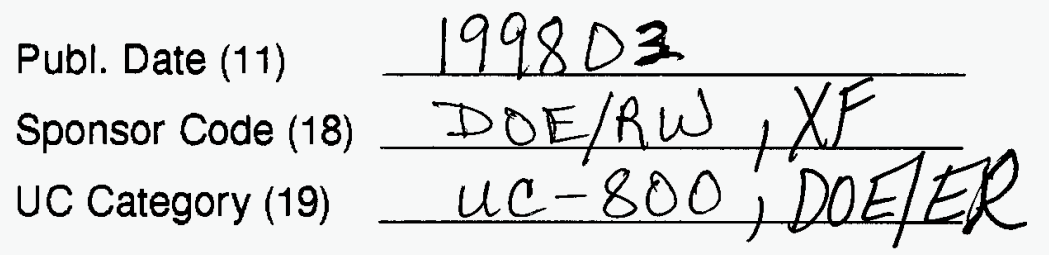

\section{2}

DTTC QUALTTY INOPECTRED 1

DOE 